\title{
(๔) $w$
}

ISSN 2450-6486

www.ehs-ss.pl

DOI: 10.38014/ehs-ss.2020.1.12

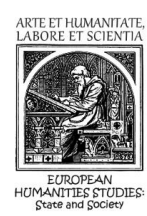

\section{Валентина ТАРАСУН}

\section{Стандартизація як механізм управління процесом розвитку i навчання дітей 3 аутизмом}

Постановка проблеми. Результати сучасних наукових досліджень проблем аутології показують, що в їхньому вирішенні досягнуто значних успіхів, на що, загалом, вказують зміни сучасних уявлень про аутизм. Водночас на сьогодні ми є свідками багатопланової наукової неузгодженості, що розгорнулася між поведінковими i нейробіологічними науками, між психологопедагогічною спільнотою і нейронауковцями, між науковцями і особами з аутизмом та їхніми батьками. Вирішення цих дискусійних питань потребуе значних зусиль як в теоретичному, так i в практичному планах.

Аналіз досліджень і публікацій. Сутність неузгодженості в їхньому розв'язанні стосується вирішення таких важливих проблем аутології, як: визначення поняття «аутизм» (хвороба чи порушення розвитку, альтернативна норма, довічний нейропсихологічний розлад, альтернативний розвиток, нейрорізноманітність) і використання відповідних аутодогічних термінів; вибору підходів 
до діагностики, зокрема ранньої діагностики аутизму (орієнтація на поведінково-симптоматичний чи інструментадьний підходи); обрання методів (дікування чи поведінкова терапія) при виборі медикаментозних, поведінкових і синтетичних методів; вибору методик для корекційно-розвивального втручання; обрання символу аутизму [1-8].

Серед цих дискусійних проблем ми виділяемо важливу проблему забезпечення стандартизації навчання і розвитку дітей 3 аутизмом. Неузгодженість у даному випадку полягає в тому, що частина наукової спільноти вважає, що в роботі з аутичними дітьми доцільно застосувати стандартизацію та іï основний принцип - програмно-цільове планування. Інші науковці і практики категорично проти, мотивуючи своє рішення мультифакторністю аутизму і надто тонкими специфічними закономірностями розвитку цієї категорії дітей.

Мета статті подягає у висвітлені можливих шляхів впровадження уніфікації як методу стандартизації і одного з елементів механізму управління процесом розвитку і навчання дітей з аутизмом.

Виклад матеріалу досдідження. Необхідність застосування уніфікації, тобто ефективного методу скорочення зайвого різноманіття спеціальних методів, технік, методик, прийомів, завдань 3 метою приведення корекційно-розвиткового процесу на певних його етапах до єдиної системи і однотипності, ми обгрунтовуємо декількома позиціями. Найперше, що необхідно зазначити, в проблемі уніфікаціі наукова спільнота виділяе такий важливий фактор, як превалентність аутизму. Це показник загальної кількості роздадів аутизму за певний період часу на відміну від інцидентності, тобто кількості нових випадків розладів в популяції у певний період часу. На сьогодні за останніми (2017) даними статистики Центру по контролю і профілактиці захворювань США аутизм спостерігався в 1 дитини 3 68, а 326 квітня 2018 року ця цифра змінилася - 1 дитина 3 59. Водночас є окремі дані, за якими у 2018 році ця статистична цифра становила для хлопчиків 1 з 28, для дівчат - 1 з 80. Крім того, за результатами медичної статистики, встановлено, що за останні 10 років розповсюдженість аутизму у світі збільшилася на порядок, тобто у 10 разів і що кожні 20 хвилин у світі реєструється новий випадок аутизму.

Інший фактор - це розв'язання одного 3 ключових завдань аутології, пов'язаного зі зняттям науковою спільнотою гендерного 
упередження (відомого співвідношення 1:4), що, безумовно, вплине на зростання показників превалентності аутизму. Адже на сьогодні вже доведено: таке співвідношення є результатом того, що аутичні прояви в дівчат виявити значно складніше, оскільки у переважної їхньої більшості вони вдало маскуються, зокрема краще розвиненим мовленням. У цьому зв'язку висловлюеться думка, що для багатьох дівчаток істотно вищим (у порівнянні з хлопчиками) є ризик того, що їх аутизм не буде діагностовано не тільки своєчасно, а й узагалі.

Наступний фактор зростання показників превалентності пов'язаний 3 тим, що на сьогодні аутизм діагностують не тільки (як ще в недалекому минулому) у дітей з порушеннями інтелектуального розвитку, а й у середньо- і високофункціональних нейротипових дітей. Як один із насдідків такої зміни у погдядах науковців, діти цієї категорії в дитячих закладах освіти вже не розгдядаються як переважно розумово відсталі. Окрім того, за останніми даними зарубіжних авторів, в міру зростання превалентності аутизму показники розповсюдженості інтелектуальної недостатності стали помітно зменшуватися.

В Україні, за офіційною статистикою МОЗ, в останні роки кількість аутичних розладів зросла на 194\%. Ця цифра, власне, не повинна викликати надто сильне занепокоєння, якщо вона і занижена. Як показує історія аутології, то, наприклад, за результатами дослідження, здійсненого у 2003 році американськими ученими, які досліджували показники соціальнихаспектів аутизму, було встановлено збільшення кількісних даних щодо постановки діагнозу аутизму в Каліфорнії на 634\% (з 1987 до 2003 року). Проте, як зазначають українські учені, все ж серйозна проблема полягає в тому, що в країні досі не досліджена кількість дітей 3 аутизмом. Тобто, не відомо, чи ці показники відповідають світовій статистиці по поширеності даного роздаду чи ні? Це близько 1\% дитячого населення країни, чи це менше? На сьогодні ж кількість таких дітей в Україні (за доступними даними) не збігається з показниками як загальносвітовими, так і заявленими MO3 України. Дійсну ж розповсюдженість аутизму встановити в Україні чи у різних їі регіонах поки що неможливо, що пов' язано як зі статистичною реєстрацією (кодування може проводитися за трьома класами хвороб МКХ-11), так і через недостатню розробленість діагностичних та методологічних підходів своєчасної діагностики.

Отже, на нашу думку, вивчення превалентності роздадів спектру аутизму є нагальним завданням українських вчених, оскільки 
аутологічної допомоги потребуватиме все більша кількість дітей. Як наслідок, все складніше буде ії здійснювати виключно індивідуально чи 3 малочисельними групами. Своєю чергою, це вимагатиме знаходження шляхів стандартизації такої допомоги за рахунок впровадження уніфікованих методів.

У цьому зв'язку ще раз зазначимо важдивість започаткування грунтовних наукових досліджень в галузі аутології, спрямованих на розв' язання проблеми превалентності аутизму в Україні і покликаних з'ясувати справжню чиседьність дітей з аутизмом. Не повідомляючи про те, скільки людей в Україні мають РАС, немождиво, на нашу думку, вибудувати грамотну систему державної допомоги їм в галузі охорони здоров'я, освіти і соціального захисту.

На зростання показників поширеності аутизму в дітей, а відтак на необхідність знаходження методів уніфікації роботи 3 ними впдивають також успішні зарубіжні розробки новітніх технік ранньої діагностики аутизму. При цьому особливо важдивими є дослідження в галузі генетики, якими доводиться зв'язок між маркерами аутизму і станом розвитку мозку. Досягнуто обнадійдивих результатів досліджень про можливість в майбутньому уповільнити зростання показників превалентності аутизму. Прикладом цього може бути розробка такого нового діагностичного інструменту, як аналіз крові, який проходить остаточну перевірку i, як стверджують нейробіологи, незабаром може стати стандартним для постановки діагнозу «аутизм».

На сьогодні ж до об'єктивного зростання частоти діагнозу РАС призводить також удосконалення методів виявлення аутизму, особливо застосування технік ранньої діагностики, широке впровадження удосконалених критеріїв, викладених у таких діагностичних і статистичних керівництвах по психічних роздадах, як MKX і DSM, широка поінформованість і обізнаність суспільства, підтримка держави. Як наслідок, зростання превалентності аутизму вже зараз призводить до ведичезного навантаження на недостатню кількість, недостатньо підготовдених до аутодогічної допомоги фахівців. Особливо тиск такого навантаження є суттєво найбільшим на початковому етапі такої роботи, коди повноцінне врахування індивідуадьного варіанту розвитку дитини є значною мірою не можливим. У практичному плані це пов'язано, перш за все, 3 тим, що при визначені загальних і специфічних закономірностей розвитку дітей з особливостями в розвитку загадом і з аутизмом 
зокрема, специфічні особливості представлено не індивідуальним, а узагальненим варіантом розвитку.Навіть за останнімипереглянутими діагностичними критеріями розладів аутизму (DSM-5) - це чіткий набір класичних симптомів аутизму з виділенням вже навіть не трьох, а двох сфер порушень - дефіцит соціального спілкування й обмежені, повторні форми поведінки. Додатково в DSM-5 передбачається виділення: гіпер-/гіпоактивність сенсорного сприйняття і незвичні сенсорні інтереси дитини. Ця обставина унемождивдюе повноцінне урахування індивідуального варіанту розвитку дітей з РАС, зважаючи, окрім того, на реальне співвідношення кількості спеціалістів у дошкільних і шкільних освітніх закладах.

На наше переконання, упровадження уніфікованого підходу створить умови для орієнтації процесу розвитку і навчання дітей 3 аутизмом наспільністьвимогдозмісту, якийможебутипредставлений в освітніх стандартах. У цьому зв'язку постає вирішальне і життево важливе для дитини та ії сім’ї питання: що необхідно зробити, щоб допомогти такій дитині? Адже рішення про те, яку в цей період допомогуїй надати (чи ненадати), значною мірою визначитьії життєві перспективи. Вирішенню цієї проблеми, на нашу думку, можуть сприяти розробка і впровадження саме уніфікованого підходу. При цьому важливими стають поодинокі спроби фахівців вже сьогодні розробити стандарти з визначенням сукупності основних вимог до порядку та умов здійснення кваліфікованої аутологічної допомоги. I такі, офіційно не затверджені, спроби стандартизації вже є.

Як показуе здійснений нами аналіз та узагальнення наукової літератури, для досягнення мети уніфікації можна йти різними шляхами, які розробляються в сучасних (в основному зарубіжних) психолого-педагогічних дослідженнях і в нейронауках. Важливим, на нашу думку, є те, що ці два різні шляхи, два підходи об'єднує ідея про те, що магістральним шляхом досягнення уніфікації, тобто приведення до одноманітності, до єдиної форми, єдиної системи роботи, має стати шлях стратифікації (розшарування) симптомів аутизму. У даному разі - це поділ дітей з аутизмом на спеціальні групи (страти) шляхом об'єднання різноманітних емоційних, соціальних, комунікативних симптомів з приблизно однаковими проявами за декількома стратифікаційними критеріями (показниками). Перший шлях - це шлях, який пропонують психологи і педагоги, спрямований на розширення діагностики спектра аутичних порушень у дітей. Хоча це питання є надзвичайно складним, адже, наприклад, нейробіологи 
взагалі протестують проти терміну РАС, вважаючи його безформною глибою і звалищем симптомів. При цьому, однак, визнають, що на сьогодні поведінкові методики здатні подіпшити якість життя дітей 3 аутизмом та їхніх родин.

Отже, перший шлях - це розширення діагностики так, як його пропонують здійснювати психологи і нейропсихологи. При цьому доводиться мождивість в роботі 3 дітьми 3 аутизмом застосувати метод стратифікаціі (розшарування) симптомів аутизму з виділенням трьох його форм [2, 6]. Це, так звані, відчужені діти, з низьким рівнем свідомості і серйозними порушеннями поведінки (агресією, стереотипіями, маніпулятивною грою). Гіпоактивні, пасивні діти 3 крайнім обмеженням соціальних контактів, які не одержують задоволення від пропонованого спілкування і мають систематичну безпосередню ехолалією. Третя група - це гіперактивні діти, які також мають відхилення в поведінці, але більш складні: повторне розігрування одних і тих же ситуацій, абстрактні інтереси при повній відсутності інтересу до всього іншого і при відсутності практичної спрямованості в діях. Доводиться, що використання в педагогічній практиці такого розширення діагностики РАС може зробити роботу 3 дітьми більш уніфікованою, з одного боку, але водночас і диференційованою і більш успішною на основі програмно-цільового планування, тобто стандартизації роботи. Однак відразу зазначу, що у наукової спільноти подібне розширення діагностики спектра аутичних розладів поки що викдикає певний сумнів, хоча водночас вважається виключно перспективним.

Другий шлях досягнення розшарування симптомів пропонуеться здійснити з урахуванням результатів досліджень вже в галузі нейронаук. На цьому етапі спеціаліст в процесі діяльності має вирішити питання: яким чином сприяти стимулюванню функцій кіркових і особливо підкіркових структур мозку дитини. Адже саме підкіркові структури, ці психофізіологічні механізми забезпечують необхідний рівень енергетики, тонусу кори, визначально впливаючи на здатність мозку сприймати, переробляти і зберігати інформацію та видавати результати цієї переробки.

Доводиться, що такий підхід здатен певною мірою знівелювати (у позитивному плані) протиріччя між індивідуалізацією та стандартизацією процесу навчання. Своєю чергою, це, на нашу думку, створить умови для орієнтації навчально-розвивального процесу на дотримання спільних вимог до змісту, представлені (вимоги) 
вже загадьними освітніми стандартами, що особдиво важдиво в умовах інклюзивної освіти. Зрозуміло, що для застосування цього підходу аутолог має бути добре обізнаним з результатами наукових досліджень і враховувати їх у практичній роботі. Зокрема, в недалекому майбутньому фахівцю необхідно буде в роботі врахувати клітинні та молекулярні основи аутизму. Адже достатньо обнадійдивою є заява нейронауковців про те, що поки психодоги і педагоги будуть сперечатися: аутизм - це хвороба чи порушення розвитку, нейронауковці вже навчаться його лікувати. Нейробіологи вважають, що такі ліки будуть широко використовуватися через 10 років, але вони не входитимуть в той набір, яким традиційно користується психіатрія.

Отже, і в даному випадку знову таки пропонуеться стратифікація, розшарування дітей 3 аутизмом, але вже орієнтуючись не на поведінкові симптоми, а на нейрофізіологічні і генетичні причини його виникнення. Більше того, нейробіологами на сьогодні уже стратифіковано дві узагальнюючі каузальні групи аутизму 3 урахуванням його клітинних і молекулярних механізмів - це синдромальний та ідіопатичний («істинний», внутрішній, не пов'язаний із зовнішніми причинами) аутизм. На підставі цієї стратифікації розпочато створення i впровадження новітнього уніфікованого програмно-цільового планування в роботі 3 такими складними групами дітей.

Педагог же, знаючи результати останніх наукових досліджень, зможездійснюватинепрямийстимулюючий впливнадіяльністьмозку дитини, застосовуючи в роботі спеціально розроблені уніфіковані комплекси корекційно-розвиткових завдань, що базуються на результатах генетичних, нейробіологічних і нейропсихологічних досліджень. Зокрема, важливим, на нашу думку, може стати застосування нейробіологічного положення про стратифікацію каузадьних груп дітей з аутизмом. Водночас не менш важливим для аутологічної роботи є врахування фахівцями положення про особливості синаптичного прунінгу, тобто видалення за допомогою спеціальних нейропсихологічних методик надлишкових нейронних зв'язків, які ускладнюють засвоєння дитиною нової інформації. У підсумку, як доводять нейробіологами, це забезпечить підвищення ефективності нейросітки в дітей 3 аутизмом. Базуючись на цих знаннях, стає можливим на початковому етапі аутологічної роботи використати уніфіковані методики, розроблені на засадах стандартизації. 
Висновок. Таким чином, застосування уніфікованого методу в роботі 3 дітьми 3 аутизмом за умови, якщо цей метод не декларуватиметься, а впроваджуватиметься в навчальний процес, безумовно, вимагатиме від педагогів овододіння досить скдадними знаннями і вміннями та значної додаткової роботи. Проте, на переконання науковців, нехтування ним створює значно серйозніші проблеми, потребуючи не тільки від дитини, але й від педагога ще більше сил і часу $\mathrm{i}$, можливо, зі значно гіршим результатом.

Водночас науковці, інтенсивно розробдяючи сучасні методи і методики кваліфікованої допомоги дітям з аутизмом, попереджають про необхідність знаходження ефективних шляхів зниження показників превалентності аутизму. Учені і громадські діячі переконані, якщо не зупинити зростання показників превалентності аутизму, то ще, можливо, невідомо, хто кого буде діагностувати, хто кого буде вважати нейротипіком. Про це свідчить і те, що ця ж проблема стає також темою літераторів. Зокрема, автори книжки «Чому Джоні не махає руками» Клей і Гайдь Мортон [10] талановито показали, що (вразі подадьшого зростання показників превалентності аутизму) дюдство, особливо молоде покодіння, має бути готовим до мождивої кардинадьної зміни структури всього суспільства. У своїй книжці вони показали, так би мовити, можливий прообраз майбутнього суспільства, якщо не будуть змінені показники превалентності у світі.

Отже, літературний герой, хлопчик Нік, в якого діагностований аутизм, розповідае про свого друга Джоні, в якого, як каже його мама, не має аутизму і тому його мозок працює по-іншому. Нік вважає, що це нормально, хоча при цьому Джоні дивує його своєю поведінкою. Так, Нік розповідає, що у Джоні, ну, просто жахливо 3 пунктуадьністю: повинен, наприклад, прийти в гості о 4:00 годині, але він приходить в 3:58 або 4:03. Не вміє до того ж кожного разу зберігати однаковий порядок гри: спочатку граємо в шахи, а потім в шашки. I так повинно бути завжди. А особливо некомфортно 3 Ніком спілкуватися через те, що він, коли говорить, то дивиться прямо в очі. Окрім того, він не знає, як проявляти свої емоції: не махає руками, не підстрибує. Він просто розкриває рота і відкриває очі трохи ширше. У нього ніколи не буває істерики, коли, наприклад, спрацьовуе пожежна сигналізація. Він просто замикае свої почуття в собі. Дивно, але у Джонні немає теми, про яку він знав би все. А ще у нього проблеми з комунікацією. Він, наприклад, говорить, що 
контрольна з математики була «простіша пареної ріпки», хоча має на увазі, що вона була дуже легкою. Але Нік каже, що зрештою навчився розгадувати дивні фрази Джека. Мама Ніка пояснила йому, що це все тому, що Джоні нейротипова дитина і у нього мозок працює поіншому. «Ну, що ж, - вважає Нік, - це, мабуть, нормально і ми все ж таки зможемо грати в наші улюблені ігри».

Перспективи подальших досдіджень. Подальших пошуків у напрямі дослідження вимагає: чітке визначення об'єкту і сфери національної, регіональної ци адміністративно-територіальної стандартизації проблеми розвитку і навчання дітей 3 аутизмом, розгорнуте напрацювання низки загальних і спеціальних методичних принципів стандартизації в галузі спеціальної та інклюзивної освіти дітей 3 аутизмом, розробка положення для загадьного та неодноразового використання наявних або потенційних завдань, спрямованих на досягнення оптимального ступеня впорядкованості початкового етапу розвитку і навчання дітей з аутизмом, забезпечення процесу розроблення, видання та застосування стандартів.

\section{References:}

1. Аль-Мраят О.Б. (2019). Особливості формування графо-моторних навичок у мододших школярів з аутизмом (Автореф. дис.. канд.. психол. наук). Київ.

2. Akhutina T.V., Korneev A.A., Matveeva E.Yu., Agris A.R. (2015). Age-related changes of higher mental functions in 7-9-years old children with different types of state regulation deficits // Psychology. Journal of the Higher School of Economics. Vol. 12. N 3. P. 131-152.

3. B.A., Glasgow R.E. (2012) Dissemination of interactive health communication programs. Interactive health communication technologies: Promising strategies for health behavior change. New York, NY: Routledge,.

4. Григоренко Е. (2018) Расстройства аутистического спектра: вводный курс: учебное пособие для студентов. Москва : Издательство «Практика». 280 с.

5. Rabin B.A., Hlazhou R.E. (2012) Poshyrennya interaktyvnykh prohram komunikatsiyi zi zdorov"yam. Interaktyvni komunikatsiyni tekhnolohiyi $\mathrm{v}$ haluzi okhorony zdorov'ya: perspektyvni stratehiyi zminy povedinky $\mathrm{v}$ haluzi okhorony zdorov'ya N'yu-York, N'yu-York: Routledge.

6. Stroganova T. A., Kozunov V. V., Posikera I. N., Galuta I. A., Gratchev V. V., \& Orekhova E. V. (2013). Abnormal Pre-Attentive Arousal in Young Children with Autism Spectrum Disorder Contributes to Their Atypical Auditory Behavior: An ERP Study. PloS one.. №8 2013 (7). P. 6-10.

7. Тарасун В.В. (2018) Аутологія: теорія і практика: підручник. Київ: ВАДЕКС. 590 c.

8. Чуприков А. П., Хворова Г. М. (2012). Роздади спектра аутизму: медична та 
психолого-педагогічна допомога. Львів: Мс, 184 с

9. Тарасун В.В. Етапи формування когнітивних стратегій поведінки у дітей з аутизмом (програмування, контролю, обробки інформації)//Дефектологія, 2005, стор. 8-15.

10. https://snob.ru/profile/29935/blog/137056//

11. https://proautism.info/pochemu-dzhonni-ne-mashet-rukami-klej-i-gajl morton/.

12. https://ru.wikipedia.org/wiki.

\section{Transliteration of References:}

1. Al'-Mrayat О.Б. (2019). Osoblyvosti formuvannya hrafo-motornykh navychok u molodshykh shkolyariv z autyzmom (Avtoref. dys.. kand.. psykhol. nauk). Kyiv.

2. Akhutina T.V., Kornyeyev A.A., Matvyeyeva E.YU.,Ahris A.R. (2015). Vikovi zminy vyshchykh psykhichnykh funktsiy u ditey 7-9 rokiv z riznymy typamy defitsytu derzhavnoho rehulyuvannya // "Psykholohiya. Zhurnal Vyshchoyi shkoly ekonomiky". 12(3). 131-152.

3. B.A. Hlazho R.E. (2012) Poshyrennya interaktyvnykh prohram komunikatsiyi zi zdorov"yam. Interaktyvni komunikatsiyni tekhnolohiyi $\mathrm{v}$ haluzi okhorony zdorov'ya: perspektyvni stratehiyi zminy povedinky v haluzi okhorony zdorov'ya N'yu-York, N'yu-York: Routledge.

4. Hryhorenko YE. (2018) Rozlady spektru autyzmu: vstupnyy kurs: navchal'nyy posibnyk dlya studentiv. Moskva: Vydavnytstvo «Praktyka».

5. Rabin B.A., Hlaz hou R.E. (2012) Poshyrennya interaktyvnykh prohram komunikatsiyi zi zdorov"yam. Interaktyvni komunikatsiyni tekhnolohiyi $\mathrm{v}$ haluzi okhorony zdorov'ya: perspektyvni stratehiyi zminy povedinky $\mathrm{v}$ haluzi okhorony zdorov'ya N'yu-York, N'yu-York: Routledge.

6. Strohanova T. A., Kozunov V. V., Posikera I. N., Haluta I. A., Hratchev V. V., i Orekhova YE.V. (2013). Nenormal'ne poperednye uvazhne zbudzhennya u ditey molodshoho viku z rozladom spektra autyzmu spryyaye yikh atypoviy povedintsi slukhu: ERP-doslidzhennya. Ploshcha odna. 8(7). P. e69100. Koefitsiyent vplyvu.

7. Tarasun V.V. (2018) Autolohiya: teoriya i praktyka: pidruchnyk. Kyyiv: VADEKS.

8. Chuprykov A.P., Khvorova H.M. (2012). Rozlady spektra autyzma: medychna ta psykholoho-pedahohichna dopomoha. L'viv: Ms.

9. Tarasun V.V. (2005). Etapy formuvannya kohnityvnykh stratehiy povedinky u ditey z autyzmom (prohramuvannya, kontrolyu, obrobky informatsiyi)// Defektolohiya. 8-15.

10. https://snob.ru/profile/29935/blog/137056//

11. https://proautism.info/pochemu-dzhonni-ne-mashet-rukami-klej-i-gajl-morton/.

12. https://ru.wikipedia.org/wiki. 
The Author

Tarasun Valentyna

Doctor of Pedagogical Sciences, Professor,

Professor of the Department of Speech Therapy

and Logopsychology,

Special and Inclusive Education Faculty,

National Pedagogical University

by M.P. Dragomanov,

Kyiv, Ukraine

Email:vtarasun@gmail.com

Abstracts

TARASUN WALENTYNA. Standaryzacja jako mechanizm zarządzania procesem rozwoju i nauczania dzieci z autyzmem. Artykut dotyczy stanu badan nad kontrowersyjnym problemem standaryzacji procesu nauczania i rozwoju dzieci z autyzmem. Celem artykutu jest przedstawienie możliwych sposobów wdrożenia unifikacji jako metody standaryzacji procesu rozwoju i nauczania dzieci z autyzmem. Przez unifikację rozumiemy skuteczna metodę zmniejszania niepotrzebnej różnorodności specjalnych metod, technik, podejść, sposobów, zadań w celu doprowadzenia procesu korekcji i rozwoju na jego pewnych etapach do jedynego systemu i jednolitości. Jednym $z$ determinujacych powodów, dla których warto zastosować metodę unifikacji, jest rozpowszechnienie - stale rosnacy wskaźnik ogólnej ilości zaburzeń autystycznych w określonym okresie. W konsekwencji lekarzom coraz trudniej jest dostosowywać korekcje rozwoju dzieci wyłacznie indywidualnie lub w małych grupach. Wymaga to znalezienia sposobów standaryzacji takiej pomocy poprzez wprowadzenie unifikacji za pomoca metody stratyfikacji, tj. rozwarstwienie objawów. Pierwszy sposób zaproponowany przez psychologów i neuropsychologów jest ukierunkowany na poszerzenie diagnozy spektrum zaburzeń autystycznych u dzieci z podziatem go na trzy formy. Drugi sposób osiagnięcia stratyfikacji jest proponowany na poczatkowym etapie prac korekcyjnych i rozwojowych, z uwzględnieniem wyników badań w dziedzinie neuronauki dotyczacych pośredniej stymulacji funkcji korowych i podkorowych struktur mózgu dziecka. Wprowadzenie ujednoliconego podejścia stworzy warunki dla ukierunkowania procesu rozwoju $i$ 
nauczania dzieci z autyzmem na powszechność wymagań dotyczacych treści, które można przedstawić $w$ standardach edukacyjnych.

Stowa kluczowe: standaryzacja, prewalencja, metody zunifikowane, stratyfikacja, dzieci z autyzmem.

\section{ВАЛЕНТИНА ТАРАСУН. Стандартизація як механізм управ-} діння процесом розвитку i навчання дітей з аутизмом. $У$ статті висвітлюються стан дослідження дискусійної проблеми стандартизациї процесу навчання $і$ розвитку дітей з аутизмом. Мета статті полягае у висвітлені можливих иляхів впровадження уніфікації як методу стандартизації процессу розвитку і навчання дітей з аутизмом. Під уніфікацією ми розуміємо ефективний метод скорочення зайвого різноманіття спеціальних методів, технік, методик, прийомів, завдань дяя приведення корекційно-розвиткового проияесу на певних його етапах до єдиної системи і однотипності. Однією з визначальних причин звернення до методу унібікації є превалентність - невпинно зростаючий показник загальної кількості розладів аутизму за певний період часу. Як наслідок, аутологу все складніше здійснювати корекцію розвитку дітей виключно індивідуально чи з малочисельними групами. Ця обставина вимагае знаходження иляхів стандартизациї такої допомоги за рахунок впровадження уніфікації із застосуванням методу стратифікації, тобто розщарування симптомів. Перший шлях, який пропонують психологи і нейропсихологи, спрямований на розширення діагностики спектра аутичних порушень у дітей з виділенням трвох його форм. Аругий илях досягнення стратифікації пропонуеться здійснити на початковому етапі корекційно-розвиткової роботи з урахуванням результатів досліджень в галузі нейронаук про непряме стимулювання функцій кіркових і підкіркових структур мозку дитини. Упровадження унібікованого підходу створить умови для орієнтації процесу розвитку і навчання дітей з аутизмом на спільність вимог до змісту, який може бути представлений в освітніх стандартах.

Ключові слова: стандартизація, превалентність, унібіковані методи, стратифікація, діти з аутизмом.

ВАДЕНТИНА ТАРАСУН. Стандартизация как механизм управления процессом развития и обучения детей с аутизмом. В статье освещаются состояние исследования дискуссионной проблемы стандартизациии процесса обучения и развития детей с аутизмом. Цель статьи заключается в освещении возможных путей 
внедрения унификации как метода стандартизации процесса развития и обучения детей с аутизмом. Под унификациией мь понимаем эффективный метод сокращения хищнего многообразие специиальных методов, техник, методик, приемов, заданий для приведения коррекциионно-развивающего процесса на определенных его этапах в единую систему и однотипности. Одной из определяющих причин обращения к методу унификации является превалентнисть - постоянно растущий показатель общего количества расстройсть аутизма за определенный период времени. Как следствие, аутологу все сложнее осуществлять коррекцию развития детей исключительно индивидуально или с малочисленныли группами. Это обстоятельство требует нахождения путей стандартизации такой помощци за счет внедрения унификации с применением метода стратификаизии, то есть расслоение силптомов. Первый путь, который предлагают психологи и нейропсихологи, направленный на расширение диагностики спектра аутичных нарушений у детей с выделением трех его форм. Второй путь достижения стратификации предлагаетсл осуществить на начальном әтапе коррекицонно-развивающей работы с учетом результатов исследований в области нейронаук о косвенном стимулирования функичий корковых и подкорковых структур мозга ребенка. Внедрение унифицированного подхода создаст условия для ориентации процесса развития и обучения детей с аутизмом на общность требований к содержанию, который может быть представлен в образовательных стандартах.

Ключевье слова: стандартизация, превалентнисть, унифицированные методы, стратификация, дети с аутизмом.

VALENTINA TARASUN. Standardization as a mechanism for managing the development and learning of children with autism. The article deals with the state of research of the discussion problem of standardization of the process of learning and development of children with autism. The purpose of the article is to highlight possible ways of implementing unification as a method of standardizing the process of development and education of children with autism. By unification we mean an effective method of reducing the unnecessary variety of special methods, techniques, techniques, techniques, tasks for bringing the correction and development process at certain stages to a single system and uniformity. One of the decisive reasons for resorting to the unification method is the prevalence - a steadily increasing rate of total autism disorders over a period of time. As a consequence, it is increasingly 
difficult for autologists to adjust their development to children alone or with small groups. This necessitates finding ways to standardize such care through the introduction of unification using the stratification method, ie the stratification of symptoms. The first path offered by psychologists and neuropsychologists is to expand the diagnosis of the spectrum of autistic disorders in children with the separation of its three forms. The second way to achieve stratification is proposed at the initial stage of correction and development work, taking into account the results of research in the field of neuroscience about indirect stimulation of the functions of the cortical and subcortical structures of the brain of the child. The introduction of a unified approach will create the conditions for orienting the process of development and education of children with autism to the commonality of content requirements that can be presented in educational standards.

Keywords: standardization, prevalence, unified methods, stratification, children with autism. 